\title{
Development of gluten-free and egg-free pasta based on quinoa (Chenopdium quinoa Willd) with addition of lupine flour, vegetable proteins and the oxidizing enzyme POx
}

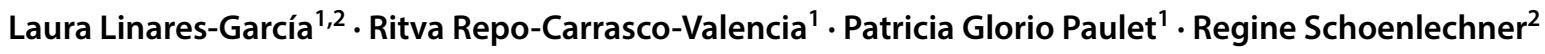

Received: 13 March 2019 / Revised: 12 June 2019 / Accepted: 15 June 2019 / Published online: 27 June 2019

(c) The Author(s) 2019

\begin{abstract}
The aim of this research was to develop gluten-free (GF) and egg-free quinoa pasta with high nutritional value. Extruded and non-extruded quinoa (red and white) flour, potato starch, tara gum, and potato, pea and rice protein isolates were investigated in different recipes, some of them included egg white as an initial reference point. Results showed that extruded quinoa flour, potato starch and tara gum had deteriorating effects on GF and egg-free pasta firmness and cooking quality. Lupine flour addition itself was not able to replace egg white when added in the same amounts, but after increasing the concentration to $12 \%$, the firmness and cooking quality decreasing effects could be improved again, especially when tara gum was absent in the formulations. In the final recipe, the content of lupine flour was increased to $30 \%$ because its protein is complementary to the quinoa protein. From the three studied protein isolates, pea protein was superior to potato or rice protein, addition of the oxidizing enzyme POx could even further improve texture firmness. After these trials, the final recipe containing lupine flour, pea protein and POx showed satisfying GF noodle quality and possessed a valuable nutritional composition with high protein and dietary fibre content.
\end{abstract}

Keywords Quinoa $\cdot$ Lupine $\cdot$ Pasta $\cdot$ Gluten-free $\cdot$ Egg-free $\cdot$ Vegetable proteins

\section{Introduction}

Pasta is one of the most popular foods in many places in the world, because of their simplicity, palatability, long shelflife, and accessible cost, qualities that have caused their worldwide production to increase from 7 to 12 million tons per year during the past decade [1-3]. The special qualities of pasta, low cooking loss, high firmness, adhesiveness and tolerance to overcooking result from the high gluten quality of durum wheat flour, which is mainly responsible for the formation of the matrix structure [4].

For persons that are sensitive to gluten (e.g. coeliac disease patients), and/or for people who wish to exclude gluten

Regine Schoenlechner

regine.schoenlechner@boku.ac.at

1 Universidad Nacional Agraria La Molina, Av. La Molina s/n, Lima, Peru

2 Department of Food Science and Technology, University of Natural Resources and Life Sciences, Muthgasse 18, 1190 Vienna, Austria from their diet for various reasons a growing interest in the development of (GF) food products has generated [5]. Currently available GF products are often based on starch, mainly from rice and maize, which results in products with a low nutritive value [1]. According to Saturni et al. [6] deficits in intake of proteins, fibres, minerals (calcium, magnesium, iron and zinc) and vitamins (folate, niacin, vitamin $B_{12}$ and riboflavin) occur. Pasta from quinoa would be a good alternative due to their high nutritional value (e.g. balanced amino acid composition) and bioactive compounds (e.g. vitamins like folate, tocopherols and flavonoids like kaempferol and quercetin) [7-9]. Another possibility to increase the nutritive value is the combination of lupine (legume with $43 \%$ of protein) and quinoa since their proteins are complemented by the composition of their limiting amino acids [8].

Many studies have focused on replacing the gluten network in pasta. Additives and texturizing ingredients like protein isolates, hydrocolloids, emulsifiers and modified starches are commonly used for their ability to improve the quality of GF pasta. Also, different production processes, such as heating, extrusion cooking, annealing, or high drying temperature, have been explored $[1,11,12$, 
14]. Heat-treated flours in which starch is already partially gelatinized could be suitable for GF pasta formulations [1, 12-16]. The ideal starch for GF pasta products should have a marked tendency to retrograde; this property generally is observed in high amylose cereals and legumes (e.g. mung bean starch) $[10,17,18]$. They could increase the viscosity of the dough matrices and give good texture and overall quality in pasta GF $[1,15,16]$. Recently, mathematical modelling is used to optimize biopolymer (starch, gums and proteins) and water interaction in GF formulation for pasta [14]. The use of non-gluten proteins in the production of GF pasta products positively affects structure, texture, sensory properties as well as nutritional quality in particular, by reducing amino acid deficits $[12,19]$. The most frequently used protein isolates in GP pasta are: egg proteins, milk proteins, whey proteins, defatted soy flour and fish powder [12, 20]. GF pasta including egg protein was reported to have good textural characteristics particularly regarding its viscoelastic behaviour (springiness, resilience and adhesiveness), while elasticity was mainly affected by dough moisture $[14,21]$. Whey protein concentrate incorporation to sweet potato produces high-quality pasta and low starch digestibility due to strong starch-protein network formation [20]. Other additives and texturizing ingredients like hydrocolloids or gums are commonly used for their ability to form a gel. They can provide high consistency, improve firmness, give body and mouthfeel to pasta [1]. Finally, enzyme technology during the production process seems to be a promising alternative. Proteins, starch and arabinoxylans (AX) are structure-building ingredients for producing GF pasta. Their contribution to the rheology in the GF system can be improved using oxidizing enzymes [24]. The applications of various enzymes have been investigated for GF products (usually bread) [12, 22-24]. From the group of oxidases, glucose oxidase (E.C. 1.1.3.4) (GO) has been used in gluten-containing systems for bread, a less common alternative, which was found to have similar effects to GO, is pyranose-2-oxidase (POx) (E.C. 1.1.3.10), although its application in food is still rare $[25,26]$. This enzyme catalyses the oxidation of $\mathrm{C} 2$ and $\mathrm{C} 3$ of mono- and disaccharides in the presence of oxygen to the corresponding dicarbonyl derivatives and $\mathrm{H}_{2} \mathrm{O}_{2}$ [27]. This oxidative reaction favours different scenarios, like the formation of S-S linkage between thiol groups of proteins $[25,26]$ which could also occur with non-gluten proteins [22]; crosslinking between arabinoxylans (AX) favoured by oxidised ferulic acid residues in the presence of $\mathrm{H}_{2} \mathrm{O}_{2}$ [24-26]; crosslinking promotion between $\mathrm{AX}$ and proteins for example, di-tyrosin and tyrosin-ferulic acid crosslinks [26], which increase water binding capacity; also starch crosslinking at glucose oxidized points has been suggested could be increase the viscosity of the dough. All of that contributes to stability of batter and end product quality because the final network is able to keep starch and water after cooking [24].

The main objective of this work was to develop a GF and egg-free quinoa pasta with high nutritional value. In detail, the following effects were studied: (1) addition of extruded quinoa flour and tara gum (2) replacing egg white protein with lupine flour and (3) adding vegetable proteins and POx-enzyme.

\section{Materials and methods}

\section{Raw materials}

Two varieties of organically grown quinoa were used: Real [white, origin Bolivia, derived from Naturmühle $\mathrm{GmbH}$ (Ebelsberg, Austria)] and Pasankalla (red, origin Perú, derived from the National Institute of Agrarian Innovation (INIA), Puno Experimental Station, Perú). Both varieties were milled to flour with a particle size $<0.35 \mathrm{~mm}$ using a pin mill (Pallmann Maschinenfabrik GmbH \& Co. K. G., Zweibrücken, Germany) for the quinoa Real and a rotor beater mill SR 300 (Retsch Co., Düsseldorf, Germany) for quinoa Pasankalla. Lupine whole flour was purchased from Raab Vitalfood Gmbh, (Rohrbach, Germany), potato starch from Roquette frères (Lestrem, France), tara gum from Avantari-International Center for Therapies and Medical Research (Lima, Perú). Potato protein (solanic 100, protein content $>90 \mathrm{~g} / 100 \mathrm{~g}$ ), rice protein (MB-rice protein FOOD S25 KG, protein content $79 \mathrm{~g} / 100 \mathrm{~g}$ ) and pea protein (MB-pea protein isolate, protein content $84-88 \mathrm{~g} / 100 \mathrm{~g}$ ) were bought from Brenntag Austria GmbH (Vienna, Austria). The POx enzyme (pyranose-2-oxidase) was produced at the University of Natural Resources and Life Sciences (Vienna, Austria) as described by Bender et al. [24]. The activity of the enzyme used was $50 \mathrm{U} / \mathrm{ml}$. One $\mathrm{ml}$ of this enzyme, equivalent to a supplementation level of $2.78 \mathrm{nkat} / \mathrm{g}$ in flour was used. This dose is within the range evaluated by Decamps et al. [28] (0.09-9.86 nkat/g of flour), who reported that this dose was the lowest needed to get a maximum effect in strengthening in yeastless bread dough [28].

\section{Extrusion cooking}

The flour of quinoa Pasankalla was extrusion cooked in a twin-screw, co-rotating extruder (DSE-32, Jinan Dingrun Machinery Co. Ltd., Jinan, Shandong, China). The screws had a diameter of $32 \mathrm{~mm}$ with a length to diameter ratio of 19. The extruder had four barrel zones from the feeder to the die; the temperature for each zone was set at 60, 80, 100 and $110{ }^{\circ} \mathrm{C}$, respectively. According to pre-trials (detailed results not presented here) the optimum moisture content for extrusion cooking of quinoa flour was determined to be $20 \%$, and 
the screw speed was set at $100 \mathrm{rpm}$. After extrusion cooking, the extrudates were dried at $40{ }^{\circ} \mathrm{C}$, milled and sieved using a rotor beater mill SR 300 (Retsch, Co, Düsseldorf, Germany). All quinoa flour samples were vacuum packed in plastic bags and stored at room temperature until use.

\section{Pasta production}

Detailed pasta (type tagliatelle) recipes are shown in Table 1. In order to develop pasta with a high content of protein and fiber without gluten and egg, experimental activities were designed in three stages as follows: In the first stage, the effect of extruded and tara gum were investigated using a basic pasta formulation elaborated in pretrials (results not shown) that yet contained egg white and potato starch. In the second stage, the basic pasta formulation was adapted according to the results achieved in stage 1 and the potential of lupine flour to replace egg white was investigated. In the third stage, the attempt was to further increase pasta firmness and with it the nutritional value of the pasta, by evaluating the effect of replacing potato starch with lupine flour in the basic recipe and studying the addition of vegetable proteins (peas, rice and potatoes) as well as the oxidizing enzyme POx.

For preparation of the pasta all dry raw materials were blended for $1 \mathrm{~min}$ at lowest speed using a Bear Varimixer $^{\mathrm{TM}}$ (RN10 VL-2, Wodschow \& Co., Broendby, Denmark); then water was added slowly within $1 \mathrm{~min}$ (to final water content according to Table 1); in the indicated tests the POx enzyme was added to the water at a concentration of $2.78 \mathrm{nkat} / \mathrm{g}$ of flour, according Bender et al. [24]. By increasing the speed to approximately $190 \mathrm{rpm}$ mixing was continued for $15 \mathrm{~min}$. The dough obtained was extruded using a laboratory-scale pasta press (Model P3; La Monferrina Co., Castell'Alfero, Italy). The die used was of band noodle shape (tagliatelle, width $10 \mathrm{~mm}$ ). The fresh pasta (about $30 \mathrm{~cm}$ in length) were put on racks and dried for $8 \mathrm{~h}$ at $60^{\circ} \mathrm{C}$.

Table 1 Recipes for pasta studying the effects of extruded quinoa flour, tara gum, lupine flour, various vegetable proteins and the enzyme POx

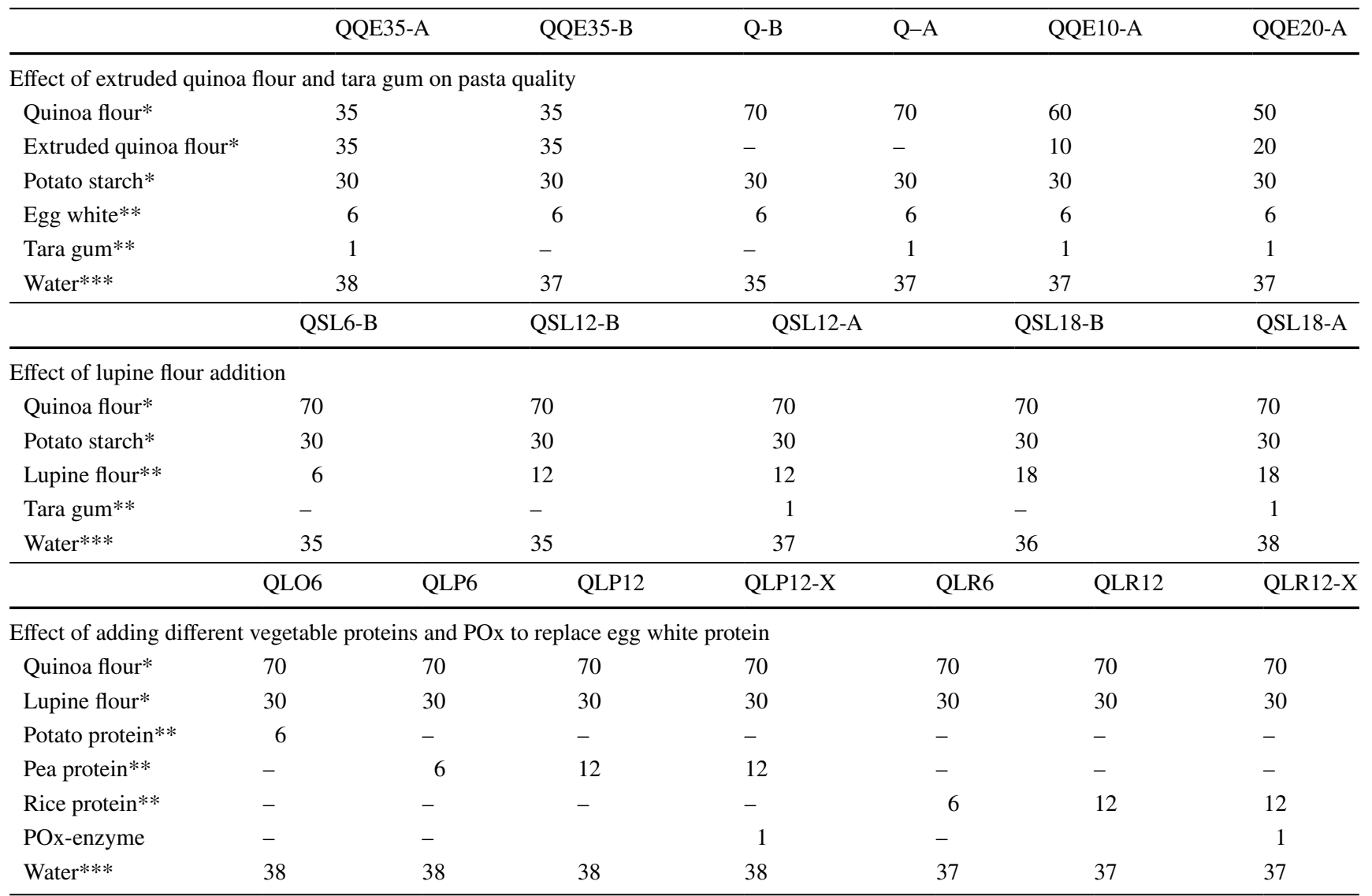

$Q$ quinoa flour, $Q E$ quinoa flour extruded, $A$ with tara gum, $B$ without tara gum, $S$ potato starch, $L$ lupine flour, $O$ potato protein, $P$ pea protein, $R$ pice protein, $X$ POx-Pyranose 2-oxidase

$* \mathrm{~g} / 100 \mathrm{~g}$ total flour

** \% based on total amount of flour

***g total water/100 $\mathrm{g}$ dough (including water content of dry ingredients) 


\section{Cooking properties of pasta}

Cooking properties were determined as described by AACCI Approved Method 66-50.01 [29]. All samples were determined in triplicate.

\section{Cooking time}

In a small cooking pot, $300 \mathrm{~mL}$ of water was heated until boiling. $25 \pm 0.5 \mathrm{~g}$ of pasta was added to the boiling water without stopping the water from boiling. In 30-s intervals, pasta was taken out and pressed between two plexiglass sheets. Cooking time corresponded to the disappearance of the white central core of the pasta.

\section{Cooking loss}

During cooking, some part of the pasta is dissolved in water. The cooking loss is determined gravimetrically by weighing the residues after evaporating the cooking water. The pasta was cooked according to the determined cooking time. Cooking water collected from each sample was evaporated until constant weight in an air oven at $105^{\circ} \mathrm{C}$. The residue was weighed and reported as percentage of the original pasta sample according to following equation:

\section{$\mathrm{CL}(\%)=$ (weight of dried residue in cooking water /dry weight of the sample) $\times 100$ \\ Cooking weight}

Cooking weight is the weight gain of the pasta during cooking. Each pasta sample was cooked according to the determined cooking time, and the cooking weight was calculated according to following equation:

$\mathrm{CW}(\%)=($ weight of cooked pasta /weight of raw pasta $) \times 100$

\section{Firmness of pasta}

The pasta was cooked in boiling water to the specific cooking time and rinsed in $25-26{ }^{\circ} \mathrm{C}$ water for $15 \mathrm{~s}$ with the help of a plastic strainer to drain the excess water. Finally, the pasta was covered with cold water in a small beaker for determination of pasta firmness using a Texture Analyzer (Model TA-XT2i, Stable Micro Systems ${ }^{\text {TM }}$ Co., Godalming, UK). A single pasta strand was placed in the centre of the measuring area and cut with a light knife blade attachment (thickness $1 \mathrm{~mm}$ ). The maximum force value was recorded as pasta firmness. Test parameters were $1 \mathrm{~mm} / \mathrm{s}$ pre-test speed, $0.1 \mathrm{~mm} / \mathrm{s}$ test speed, $10 \mathrm{~mm} / \mathrm{s}$ post-test speed; distance was adjusted to a maximum of $1 \mathrm{~mm}$ and $0.020 \mathrm{~N}$ was fixed as trigger force.

\section{Theoretical nutritional value of the obtained pasta obtained}

The proximal composition of the optimal pasta elaborated from quinoa flour, lupine flour, pea protein and POXenzyme (QLP12-X, Table 1), was calculated taking into account the per cent of each ingredient reported in Table 1. Composition data for each ingredient were derived from own measurements of the proximal composition of quinoa Real, composition reported for lupine flour from Raab Vitalfood Gmbh, (Rohrbach, Germany) and pea protein from Brenntag Austria GmbH, (Vienna, Austria). The contribution of calories per $100 \mathrm{~g}$ of pasta was evaluated considering the acceptable ranges of macronutrient distribution for healthy diets [30]. The amino acid composition of the selected pasta was calculated taking into account the amino acid composition of each ingredient. For quinoa (Real), values published by the Comité Técnico Complejo Quinua Altiplano Sur [31] were taken, for lupine flour the amino acid composition given by Raab Vitalfood Gmbh, and for pea protein the values reported by Amarakoon [32] were used. The chemical score of the protein for the selected pasta was evaluated based on amino acid requirements for adults published by WHO/FAO/UNU [33]. The calculation of amino acids adjusted for digestibility of the pasta was obtained considering a weighted average of digestibility; values previously published by Repo-Carrasco-Valencia [8] for quinoa, by Pereira Monteiro et al. [34] for Lupinus albus, and by Gabriel et al. [35] for pea were used.

\section{Statistical analysis}

The data obtained from the three experimental trials were expressed as mean \pm standard deviation (SD). Statistical effects of selected ingredients on firmness were determined by one-way analysis of variance (ANOVA). Differences between group means were analysed by Tuckey's test. When comparing only two treatments, ANOVA for two samples was applied. All tests were performed using Statgraphics centurion software version 18 (Stadpoint Technologies, Inc., The Plains, VA; USA) at significance level of $p<0.05$. 


\section{Results and discussion}

\section{Effect of extruded quinoa flour and tara gum on pasta based on quinoa flour and potato starch}

The proximal composition of quinoa Real flour was $8.9 \%$ moisture, $11.34 \%$ protein, $8.59 \%$ fat, $2.55 \%$ ash, $60.37 \%$ starch and $12.46 \%$ total dietary fibre. For quinoa Pasankalla it was $9.54 \%$ moisture, $11.7 \%$ protein, $8.3 \%$ fat, $1.88 \%$ ash, $60.60 \%$ carbohydrate and $7.98 \%$ total dietary fibre. Both quinoas have a fairly similar proximal composition, differing only in their colour due the presence of betalains in the red variety. It was chosen to evaluate red Pasakalla extruded quinoa, a variety from the Peruvian Andes, in order to give it a commercial application, increasing its consumption.

Table 2 Effects of extruded quinoa flour and tara gum on the quality of quinoa pasta

\begin{tabular}{llccc}
\hline Sample & $\begin{array}{l}\text { Cook- } \\
\text { ing time } \\
(\mathrm{min})\end{array}$ & Firmness $(n)$ & Cooking loss (\%) & $\begin{array}{l}\text { Cooking } \\
\text { weight }(\%)\end{array}$ \\
\hline Q-A & 8 & $1.17 \pm 0.08^{\alpha}$ & 8.54 & 334.56 \\
QQE10-A & 8 & $1.12 \pm 0.13^{\alpha}$ & 10.29 & 340.85 \\
QQE20-A & 8 & $1.08 \pm 0.09^{\alpha}$ & 12.03 & 345.70 \\
QQE35-A & 5 & $0.80 \pm 0.07^{\beta}$ & 15.15 & 304.44 \\
QQE35-A & 5 & $0.80 \pm 0.07^{\mathrm{a}}$ & 15.15 & 304.44 \\
QQE35-B & 5.5 & $0.95 \pm 0.09^{\mathrm{b}}$ & 7.36 & 316.32 \\
QQE35-B & 5.5 & $0.95 \pm 0.09^{\mathrm{A}}$ & 7.36 & 316.32 \\
Q-B & 7 & $1.17 \pm 0.04^{\mathrm{B}}$ & 7.69 & 379.87 \\
Q-A & 8 & $1.17 \pm 0.08^{\mathrm{B}}$ & 8.54 & 334.56 \\
\hline
\end{tabular}

Firmness expressed as mean \pm SD $(n=10)$. Different letters of the same type (Greek superscripts or lower case superscripts or upper case superscripts) indicate significant differences of the corresponding samples $(p<0.05)$

$Q$ Quinoa flour, $Q E$ Quinoa extruded, $A$ with tara gum, $B$ without tara gum
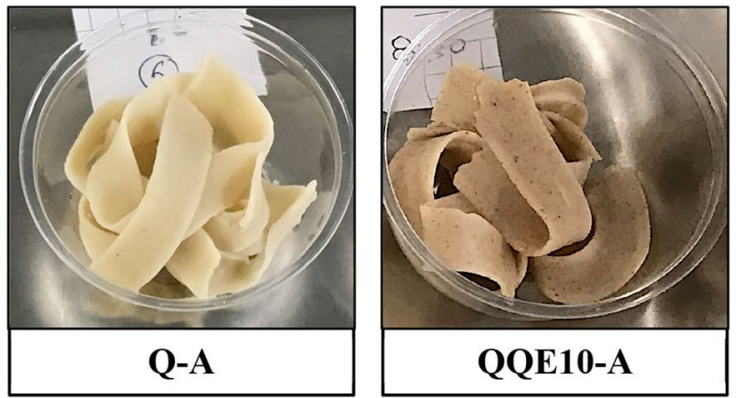

The effect of incorporating extruded quinoa Pasankalla flour to pasta is shown in Table 2 and Fig. 1. The cooking losses of the pasta ranged from 7.36 to $15.15 \%$ and were within the range of 2.2 to $21.6 \%$ found in 456 observations of 66 enriched pasta studies that were evaluated with meta-analysis by Mercier et al. [36]. Cooking weight was between 304 and $379 \%$. No clear effect of extruded flour addition could be seen, while tara gum addition seemed to decrease it. On the other hand, the firmness of the quinoa pasta was significantly influenced by the inclusion of extruded quinoa Pasankalla flour (Q-A, QQE10-A, QQE20-A vs. QQE35-A, Greek superscripts) (see Fig. 1). By addition of extruded quinoa flour, the firmness of the pasta decreased significantly $(\alpha=0.05)$; when $50 \%$ of the native quinoa flour was replaced by extruded quinoa flour, this behaviour was observed in both with (Q-A vs. QQE35-A, shown by Greek superscripts) and without gum in formulations (Q-B vs. QQE35-B, shown by upper case superscripts in the Table 2). In contrast, Cabrera-Chávez et al. [15] significantly increased the firmness of amaranth and amaranth/rice pastas by addition of extruded rice flour or extruded rice mixture with amaranth. However, Cabrera-Chávez et al. [15] also observed a smaller firmness increase in the pasta made with the extruded rice in comparison with the one that contained the extruded mixture rice-amaranth. In the case of reduction of firmness due to the use of extruded quinoa, this could be explained as due to: (1) possible reduction of the amylose content during extrusion cooking due to the formation of an amylose-lipid complex. This phenomenon was observed by Wang et al. [37], who reported significantly lower amylose and lipid values in brown rice flour after extrusion cooking, a phenomenon also observed by Lamberts et al. [38]; (2) the low content of amylose in various genotypes of quinoa (7-27\%) compared to common starches [39], where quinoa Pasankalla reports 14\% amylose [40]; (3) the susceptibility of starch granules to thermomechanical damage during extrusion cooking. Low feed humidity (FM $\leq 20 \%)$ and increasing temperature would cause a dextrinization
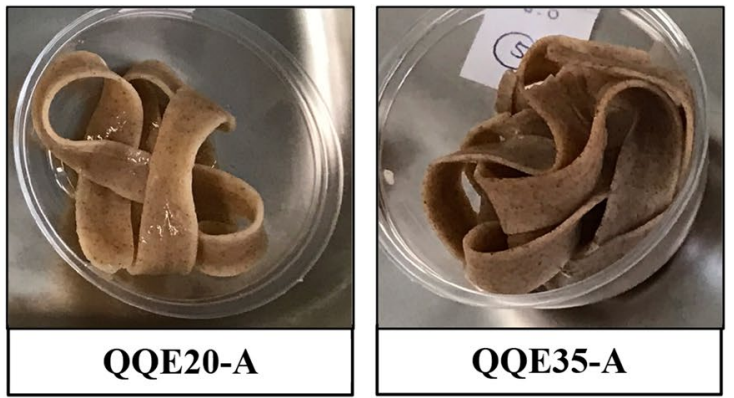

Fig. 1 Quinoa pasta (cooked); Q-A (quinoa flour), QQE10-A (quinoa flour, extruded quinoa flour 10\%) QQE20-A(quinoa flour, extruded quinoa flour 20\%) QQE35-A (quinoa flour, extruded quinoa flour 35\%) 
of starch that prevails over the gelatinization phenomenon, decreasing its water retention capacity. This is evaluated by the water absorption index (WAI) and an increase in the water solubility index (WSI) [13, 41]; (4) to the higher quantity of damaged starch caused by higher extruder screw speed. This is induced by higher mechanical shear, subsequently increasing the soluble molecules, which results in a decrease in WAI values [42], and an increase in WSI values. In this study screw speed was $100 \mathrm{rpm}$; (5) a high degree of gelatinization and degradation of the starch during extrusion at low FM levels decreases the viscosity of the pasta dough [13]; (6) the possible separation between amylose and amylopectin when subjected to high extrusion temperature would generate a matrix depending on water-binding hydrophilic groups, but due to the possible hydrophobic nature of quinoa proteins this leads to the reduction of the WAI [43].

The addition of tara gum influenced pasta firmness (QQE35-A vs. QQE35-B lower case superscripts) as well, although in the recipes Q-A and Q-B tara gum had no effect (upper case superscripts). The difference between QQE35A/B to QA/B was that the first two contained extruded flour, while the second two did not, so the firmness decreasing effect of the extruded flour was obviously further influenced by tara gum addition.

Due to the fact that extruded quinoa flour had a negative effect on the characteristics of the gluten-free quinoa pasta, causing the firmness of the quinoa pasta to decrease, it was discarded in the following trials. On the other hand, the effect of tara gum was not fully clear; thus its addition was considered again in the next trials.

Table 3 Effects of replacing egg white with lupine flour on firmness and cooking properties of cooked quinoa pasta

\begin{tabular}{lllll}
\hline Sample & $\begin{array}{l}\text { Cook- } \\
\text { ing time } \\
(\mathrm{min})\end{array}$ & Firmness $(n)$ & Cooking loss (\%) & $\begin{array}{l}\text { Cooking } \\
\text { weight }(\%)\end{array}$ \\
\hline QSL6-B & 5.5 & $0.64 \pm 0.07^{\mathrm{a}}$ & 12.04 & 360.45 \\
QSL12-B & 6.0 & $0.74 \pm 0.08^{\mathrm{b}}$ & 12.76 & 357.92 \\
QSL18-B & 7.5 & $0.75 \pm 0.06^{\mathrm{b}}$ & 12.81 & 360.23 \\
QSL12-A & 5.0 & $0.66 \pm 0.19^{\mathrm{A}}$ & 11.99 & 368.70 \\
QSL12-B & 6.0 & $0.74 \pm 0.08^{\mathrm{B}}$ & 12.76 & 357.92 \\
QSL18-A & 5.5 & $0.61 \pm 0.08^{\alpha}$ & 9.3 & \\
QSL18-B & 7.5 & $0.75 \pm 0.06^{\beta}$ & 12.81 & 360.23 \\
\hline
\end{tabular}

Firmness expressed as mean \pm SD $(n=10)$. Different letters of the same type (lower case superscripts or upper case superscripts or Greek superscripts) indicate significant differences of the corresponding samples $(p<0.05)$

$Q$ quinoa flour, $S$ potato starch, $L$ lupine flour, $A$ with tara gum, $B$ without tara gum

\section{Effects of replacing egg white with lupine flour}

Lupine flour and its proteins are well recognised for their excellent emulsifying and foaming ability, as well as its water- and fat-biding capacity; therefore, they are promising to replace egg white in many products. In Table 3 the properties of pasta with lupine flour and without eggwhite indicates that the cooking losses of the pasta made with lupine flour was between 9.3 and $12.81 \%$, thus a little lower than in the pasta prepared with egg-white (Table 2). According to Xu and Mohamed [44], the lupine proteins, mainly globulins, can form strong suspensions with water, contributing to increased viscoelastic properties. Working with Lupinus albus, the viscoelastic coefficients G' and G' were similar to gluten depending on the concentration, even though the proteins were different. They both showed similar behaviour on relaxation studies. The influence of fat in lupine was not significant for the viscoelastic properties. Firmness of the quinoa pasta was significantly influenced by lupine flour and tara gum. Compared to egg white, lupine flour replacement resulted in significant softer pasta (0.64 N in QSL6-B vs. $1.17 \mathrm{~N}$ in Q-B $(p<0.05)$. An explanation for this might be found in the findings of $\mathrm{Xu}$ and Mohamed [44], who reported that in the case of lupine suspensions the protein entanglement allowed the relaxation after a long time (favouring softer pasta characteristics). In the case of cross-linked chemical networks formed by proteins such as egg white or denatured albumin, no relaxation is possible (leading to firmer pasta). In the case of lupine suspensions the interactions between proteins are more physical and intermolecular than chemical, while in egg white a more tightly network is formed by crosslinked chemically bonding. Egg white albumins denature and expose thiol groups that favour chemical reactions of disulphide type forming network. For lupine proteins, gel formation by non-covalent interactions, such as the hydrophobic and 'Van der Waals' interactions, hydrogen and the ionic interactions, seemed to be more relevant [45-47].

There are some works that studied different proteins as structuring building ingredients for GF noodle structure. According to Marti et al. [48], egg albumen gave pasta of better appearance, with lower cooking loss $(8.1 \%)$ and firmer texture. Nutritionally they were more valuable than other proteins. Pasta made with $15 \%$ addition of liquid albumen to parboiled rice showed starch molecules homogeneously surrounded by a protein network, which was stabilized mostly by hydrophobic interactions rather than by disulfide bonds. Schoenlechner et al. [49] obtained pasta with adequate texture characteristics using 6\% egg white powder to a GF pasta formulation based on amaranth, quinoa and buckwheat. Mercier et al. [23] evaluated 66 studies of enriched pasta using meta-analysis and found 663 observations that included egg in their formulations. 
It was found that firmness of the pasta improved significantly by increasing the lupine flour content from 6 to $12 \%$, although higher increase up to $18 \%$ could not improve it further. This could be due to the fact that increasing the content of lupine flour increases the protein content directly, which would help to increase the entanglement of proteins that would trap the starches of the GF flours, increasing the viscosity of the dough and with it the firmness of the pasta. However, lupine flour showed only limited ability to perform this task; the firmness values obtained $(0.74 \mathrm{~N}, 0.75 \mathrm{~N})$ indicate that the texture characteristics of the pasta still needed to be improved with the incorporation of proteins from other sources that are able to form a network or give stability to pasta by other mechanisms.

Addition of tara gum to pasta made with lupine flour in the percentages of 12 and 18\% (QSL12-B, QSL18-B) decreased pasta firmness significantly (QSL12-A, QSL18A), which thus clarified the results obtained in the first stage (Table 2). So for the next trial series tara gum was discarded.

\section{Effects of adding vegetable proteins and the oxidizing enzyme-POx}

Firmness of the pasta made from quinoa flour (70\%) and lupine flour (30\%) was significantly influenced by the use of the oxidizing enzyme POx and the type of vegetable proteins (potato, pea or rice protein) (Table 4 and Fig. 2).

The firmness of the quinoa pasta to which pea protein was added (QLP6) was superior to the rice protein pasta (QLR6), although not significantly, but to the potato protein containing pasta it was significant. For further trials with

Table 4 Effects of adding vegetable proteins and the enzyme POX on firmness and cooking properties of cooked quinoa pasta

\begin{tabular}{lllll}
\hline Sample & $\begin{array}{l}\text { Cook- } \\
\text { ing time } \\
(\mathrm{min})\end{array}$ & Firmness $(n)$ & Cooking loss $(\%)$ & $\begin{array}{l}\text { Cooking } \\
\text { weight }(\%)\end{array}$ \\
\hline QLO6 & 5 & $0.67 \pm 0.08^{\mathrm{a}}$ & 7.96 & 377.23 \\
QLP6 & 4.5 & $0.77 \pm 0.07^{\mathrm{b}}$ & 10.30 & 289.82 \\
QLR6 & 6.5 & $0.69 \pm 0.10^{\mathrm{ab}}$ & 12.84 & 296.07 \\
QLP6 & 4.5 & $0.77 \pm 0.07^{\alpha}$ & 10.30 & 289.82 \\
QLP12 & 5 & $0.79 \pm 0.09^{\alpha}$ & 10.02 & 278.4 \\
QLP12-X & 5.5 & $0.92 \pm 0.10^{\beta}$ & 13.81 & 278.07 \\
QLR6 & 6.5 & $0.69 \pm 0.10^{\mathrm{AB}}$ & 12.84 & 296.07 \\
QLR12 & 7 & $0.60 \pm 0.07^{\mathrm{A}}$ & 13.82 & 297.42 \\
QLR12-X & 6 & $0.72 \pm 0.07^{\mathrm{B}}$ & 12.73 & 282.16 \\
\hline
\end{tabular}

Firmness expressed as mean \pm SD $(n=10)$. Different letters of the same type (lower case superscripts or upper case superscripts or Greek superscripts) indicate significant differences of the corresponding samples $(p<0.05)$

$Q$ quinoa flour, $L$ lupine flour, $O$ potato protein, $P$ pea protein, $R$ pice protein, $X$ POx-pyranose 2-oxidase

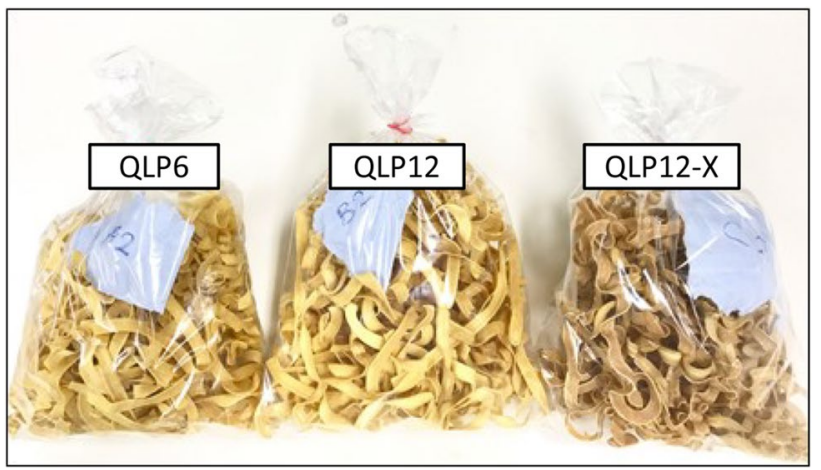

Fig. 2 Quinoa pasta: QLP6 (Quinoa flour, lupine flour 30\%, pea protein 6\%), QLP12 (quinoa flour, lupine flour 30\%, pea protein 12\%), QLP12-X (quinoa flour, lupine flour 30\%, pea protein 6\%, enzyme $\mathrm{POx})$

POx potato protein was discarded. Increasing the content of pea or rice protein from 6 to $12 \%$ had no significant improving effect on firmness.

When the oxidizing enzyme- POx was added to the quinoa pasta with $12 \%$ rice or pea protein, a significant increase in firmness was achieved. This could happen because POx favours different oxidative reactions such as formation of S-S bonds between thiol groups of proteins, cross-linking of AX and $\mathrm{AX}$, and promotion of cross-linking between proteins and AX. These phenomena have been widely tested in systems containing gluten, but Bender et al. [24] could also observe them in gluten-free systems (wholegrain millet). Sole addition of POX significantly improved the consistency and viscous properties of bread doughs based on millet. However, Bender et al. [24] mentioned that interaction with other components of flour such as proteins, or oxidation of starch, should also be considered. All this could contribute to the stability of the dough and the quality of the quinoa pasta.

\section{Nutritional indicators calculated for the improved gluten-free, egg-free quinoa pasta}

According to the obtained results in the previous trials, the quinoa pasta containing lupine flour, pea protein and POx (QLP12-X) was rated as the best recipe meeting the objective of a gluten-free and egg-free quinoa pasta. For this pasta the nutritional composition was calculated and is presented in Table 5. It was possible to obtain pasta with a content of $27.9 \%$ protein, $8.6 \%$ fat, $40.4 \%$ starch, $15.2 \%$ total dietary fiber, $2.8 \%$ ash and $7.7 \%$ humidity. The protein content of this GF and egg-free pasta (QLP-12X) was superior to most gluten-containing or gluten-free pasta. In addition, also the dietary fibre content was very high, which would allow to claim that the obtained pasta is high in protein and fibre.

According to the acceptable ranges of macronutrient distribution (ARM), the produced pasta made from 
Table 5 Chemical composition and ranges of macronutrient distribution of POx containing quinoa-lupine-pea pasta (QLP12-X)

\begin{tabular}{|c|c|c|c|c|c|c|c|}
\hline \multirow[t]{2}{*}{ Component } & \multirow[t]{2}{*}{$(\%)$} & \multicolumn{6}{|c|}{$\mathrm{g} / 100 \mathrm{~g}$ pasta } \\
\hline & & Protein & Fat & Starch & TDF & Ash & Moisture \\
\hline Quinoa flour & 62.5 & 7.1 & 5.4 & 37.7 & 7.8 & 1.6 & 5.6 \\
\hline Lupine flour & 26.8 & 11.5 & 3.2 & 2.7 & 7.4 & 0.6 & 1.4 \\
\hline Pea protein & 10.7 & 9.3 & 0.0 & 0.0 & 0.0 & 0.6 & 0.7 \\
\hline Total & 100.0 & 27.9 & 8.6 & 40.4 & 15.2 & 2.8 & 7.7 \\
\hline \multicolumn{2}{|c|}{ Energy calculation } & \multicolumn{2}{|c|}{ Kcal/100 g } & \multicolumn{3}{|c|}{$(\%)$} & $\begin{array}{l}\text { Recom- } \\
\text { mended by } \\
\text { ARM* }^{*}\end{array}$ \\
\hline \multicolumn{2}{|l|}{ Protein energy } & \multicolumn{2}{|c|}{111.7} & \multicolumn{3}{|c|}{31.9} & $10-35 \%$ \\
\hline \multicolumn{2}{|l|}{ Fat energy } & \multicolumn{2}{|c|}{77.3} & \multicolumn{3}{|c|}{22.0} & $20-35 \%$ \\
\hline \multicolumn{2}{|c|}{ Carbohydrate energy } & \multicolumn{2}{|c|}{161.6} & \multicolumn{3}{|c|}{46.1} & $45-65 \%$ \\
\hline Total energy & & \multicolumn{2}{|c|}{350.6} & & & & $360-405$ \\
\hline
\end{tabular}

*ARM Acceptable ranges of macronutrient distribution for healthy diets, according to the US Food and Nutrition Board (2005)

quinoa flour, lupine flour and pea protein contributes $350.6 \mathrm{kcal} / 100 \mathrm{~g}$ to the diet, to which the proteins contribute $31.9 \%$, fats $22.0 \%$ and carbohydrates $46.1 \%$ of total Kcal (Table 5). The Food and Nutrition Board of the United States proposes the consumption of diets that should exert a minimum risk for coronary heart disease, obesity and diabetes mellitus and regulates the contributions of macronutrients in acceptable ranges [17]. The elaborated quinoa pasta contributes a high content of protein, close to the maximum recommended values, due to carbohydrates, which are present in a smaller amount, close to the lowest recommended values. Within certain diets or circumstances (for example, malnutrition), a higher protein content can be advantageous. The fat content is within the range; additionally, these fats are of vegetable origin and, therefore, highly unsaturated, with more health benefits.

The amino acid composition and chemical score of the pasta (QLP12-X) is presented in Table 6. Leucine and valine were found to be the limiting amino acids in the pasta, with values higher than or equal to 0.9 . The true digestibility (TD) of the pasta was exceptionally high (0.91), due to the nutritional characteristics of its ingredients. The chemical score adjusted to TD concluded lysine as the limiting amino acid of the pasta, although its value of 0.99 was high. Likewise, an excellent complement was found between the amino acids methionine and phenylalanine of quinoa, lupine and pea, which delivered values of 1.43 and 1.58 , respectively. Thus, there was an excellent complementarity between the amino acids of quinoa, lupine and pea protein, as is suggested for the combination of cereal and legume proteins by RepoCarrasco-Valencia [8].

\section{Conclusions}

After numerous trials, an optimized recipe for a gluten-free and egg-free pasta from quinoa was elaborated. Several ingredients were investigated and either their amount of
Table 6 Amino acid composition and chemical score of the pasta (QLP12-X)

\begin{tabular}{lllll}
\hline Amino Acid & $\begin{array}{l}\text { Pasta QLP12- } \\
\text { X (mg AA/g } \\
\text { protein) }\end{array}$ & $\begin{array}{l}\text { WHO/FAO/UNU } \\
\text { 2007-Adults (mg AA/g } \\
\text { protein) }\end{array}$ & $\begin{array}{l}\text { Chemical } \\
\text { score pasta }\end{array}$ & $\begin{array}{l}\text { Chemical score } \\
\text { adjusted to TD* }\end{array}$ \\
\hline Phenylalanine (+ tyrosine) & 65.8 & 38 & 1.73 & 1.58 \\
Tryptophan & 7.4 & 6 & 1.23 & 1.12 \\
Methionine (+ cysteine) & 34.7 & 22 & 1.58 & 1.43 \\
Leucine & 53.3 & 59 & 0.90 & 0.82 \\
Isoleucine & 33.7 & 30 & 1.12 & 1.02 \\
Valine & 37.0 & 39 & 0.95 & 0.86 \\
Lisine & 48.8 & 45 & 1.09 & 0.99 \\
Threonine & 31.7 & 23 & 1.38 & 1.25 \\
\hline
\end{tabular}

TD* weighted true digestibility for pasta (0.91) 
addition could be defined, or they were discarded from the recipe due to deteriorating effects on pasta quality.

Addition of extruded quinoa flour was not beneficial due to its firmness lowering effect in pasta, but we cannot conclude that this will always happen with other extrusion parameters that might be chosen by industry. When egg protein was replaced by lupine flour, it was observed that the higher the lupine flour content the higher was the firmness of the pasta; however, the final values for firmness were still lower than those obtained with egg white. The texture characteristics of this system did not benefit from the incorporation of tara gum; thus its use was discarded. Comparing the addition of potato, rice or pea protein, it was identified that pea protein showed a significant increase in pasta firmness, at amounts of at least $12 \%$ protein. The addition of the oxidizing enzymePOx further improved the quality of the pasta, which suggests the formation of chemical associations cross-linked in the molecules, proving to be a good possibility to improve the GF pasta products, since so far only it has been tested in breads The optimal quinoa pasta had an adequate nutritional composition within the ranges recommended by the Food and Nutrition Board. A GF and egg-free pasta with a high protein content $(27.9 \%)$ was obtained, in addition to being a good source of dietary fibre (15.2\%). Overall, the final pasta can be considered of high nutritional value and presents thus a good alternative for human consumption.

Acknowledgements Open access funding provided by University of Natural Resources and Life Sciences Vienna (BOKU). The work for this study was part of the PROTEIN2FOOD project (European Union's Horizon 2020, No. 635727). We thank UNALM and MINEDU for the financing of an internship to the University of Natural Resources and Life Sciences Vienna (BOKU). Author Linares acknowledges a scholarship for her doctoral studies in the field of food science, from MINEDU-Perú (Project: CONV-000179-2015-FONDECYT-DE).

\section{Compliance with ethical standards}

Conflict of interest The authors declare that they have no conflict of interest.

Compliance with ethics requirements This article does not contain any studies with human or animal subjects.

Open Access This article is distributed under the terms of the Creative Commons Attribution 4.0 International License (http://creativeco mmons.org/licenses/by/4.0/), which permits unrestricted use, distribution, and reproduction in any medium, provided you give appropriate credit to the original author(s) and the source, provide a link to the Creative Commons license, and indicate if changes were made.

\section{References}

1. Marti A, Pagani MA (2013) What can play the role of gluten in gluten free pasta? Trends Food Sci Technol 31:63-71
2. Carini E, Curti E, Minucciani M, Antoniazzi F, Vittadini E (2014) Pasta. In: Guiné RPF, Correia PMR (eds) Engineering aspects of cereal and cereal-based products. CRC Press, Boca Raton p, pp 211-238

3. Li M, Zhu KX, Guo XN, Brijs K, Zhou HM (2014) Natural additives in wheat-based pasta and noodle products: opportunities for enhanced nutritional and functional properties. Compr Rev Food Sci Food Saf 13:347-357

4. Marti A, Seetharaman K, Pagani MA (2013) Rheological approaches suitable for investigating starch and protein properties related to cooking quality of durum wheat pasta. J Food Quality 36(2):133-138

5. Rosell CM, Barro F, Sousa C, Mena MC (2014) Cereals for developing gluten-free products and analytical tools for gluten detection. J Cereal Sci 59:354-364

6. Saturni L, Ferretti G, Bacchetti T (2010) The gluten-free diet: safety and nutritional quality. Nutrients 2:16-34

7. Wang S, Zhu F (2016) Formulation and quality attributes of quinoa food products. Food Bioprocess Technol 9:49-68

8. Repo-Carrasco-Valencia R (2014) Valor nutricional y compuestos bioactivos en los cultivos andinos, re-descubriendo los tesoros olvidados. Fondo Editorial: UNIVERSIDAD NACIONAL AGRARIA LA MOLINA, Lima, Peru, p 112 (ISBN 978-612-4147-34-0)

9. Nascimento CA, Mota C, Coelho I, Gueifao S, Santos M, Matos AS, Gimenez A, Lobo M, Samman N, Castanheira I (2014) Characterisation of nutrient profile of quinoa (Chenopodium quinoa), amaranth (Amaranthus caudatus), and purple corn (Zea mays L.) consumed in the north of Argentina: proximates, minerals and trace elements. Food Chem 148:420-426

10. Bhattacharya M, Zee SY, Corke H (1999) Physicochemical properties related to quality of rice noodles. Cereal Chem $76: 861-867$

11. Haros CM, Schoenlechner R (eds) (2017) Pseudocereals: chemistry and technology. Wiley Blackwell, Chichester, UK (ISBN 978-1-118-93828-7)

12. Padalino L, Conte A, Del Nobile MA (2016) Overview on the general approaches to improve gluten-free pasta and bread. Foods 5(4):87. https://doi.org/10.3390/foods5040087

13. Sarawong C, Schoenlechner R, Sekiguchi K, Berghofer E, Perry KWNG (2014) Effect of extrusion cooking on the physicochemical properties, resistant starch, phenolic content and antioxidant capacities of green banana flour. Food Chem 143:33-39

14. Gao Y, Janes M, Chaiya B, Brennan M, Brennan C, Prinyawiwatkul W (2018) Gluten-free bakery and pasta products: prevalence and quality improvement. Int J Food Sci Tech 53:19-32. https:// doi.org/10.1111/ijfs. 13505

15. Cabrera-Chávez F, Calderón de la Barca A, Islas Rubio AR, Marti A, Marengo M, Pagani MA (2012) Molecular rearrangements in extrusion processes for the production of amaranth-enriched, gluten-free rice pasta. Food Sci Tech 47:421-426

16. Bustos MC, Perez GT, Leon AE (2015) Structure and quality of pasta enriched with functional ingredients. RSC Adv 5:30780-30792

17. Lii CY, Chang YH (1991) Study of starch in Taiwan. Food Rev Int 7:185-203

18. Tan H-Z, Li Z-G, Tan B (2009) Review starch noodles: history, classification, materials, processing, structure, nutrition, quality evaluating and improving. Food Res Int 42:551-576

19. Thompson $\mathrm{T}$ (2009) The nutritional quality of gluten - free foods. In: Gallagher E (ed) Gluten-free food science and technology. Blackwell Publishing Ltd, Oxford, pp 42-51

20. Gopalakrishnan G, Menon R, Padmaja G, Sajeev MS, Moorthy SN (2011) Nutritional and functional characteristics of protein fortified pasta from sweet potato. Food Nutr 2:944-955 
21. Larrosa V, Lorenzo G, Zaritzky N, Califano A (2016) Improvement of the texture and quality of cooked gluten-free pasta. LWT Food Sci Technol 70:96-103

22. Németha R, Benderb D, Jaksicsa E, Calicchioc M, Langóa B, D’Amicob S, Töröka K, Schoenlechner R, Tömösközia S (2019) Investigation of the effect of pentosan addition and enzyme treatment on the $\mathrm{T}$ rheological properties of millet flour based model dough systems. Food Hydrocoll 94:381-390

23. Renzetti S, Arendt EK (2009) Effects of oxidase and protease treatments on the breadmaking functionality of a range of gluten-free flours. Eur Food Res Technol 229:307-317. https://doi. org/10.1007/s00217-009-1048-6

24. Bender D, Nemeth R, Cavazzi G, Turoczi F, Schall E, D’Amico S, Torok K, Lucisano M, Tomoskozi S, Schoenlechner R (2018) Characterization of rheological properties of rye arabinoxylans in buckwheat model systems. Food Hydrocoll 80:33-41

25. Decamps K, Joye IJ, Haltrich D, Nicolas J, Courtin CM, Delcour JA (2012) Biochemical characteristics of trametes multicolor pyranose oxidase and aspergillus niger glucose oxidase and implications for their functionality in wheat flour dough. Food Chem 131(4):1485-1492. https://doi.org/10.1016/j.foodc hem.2011.10.041

26. Decamps K, Gryp G, Joye IJ, Courtin CM, Delcour JA (2014) Impact of pyranose oxidase from Trametes multicolor, glucose oxidase from Aspergillus Niger and hydrogen peroxide on protein agglomeration in wheat flour gluten-starch se-paration. Food Chem 148:235-239. https://doi.org/10.1016/j.foodc hem.2013.10.036

27. Wongnate T, Chaiyen P (2013) The substrate oxidation mechanism of pyranose 2-oxidase and other related enzymes in the glucose-methanol-choline superfamily. FEBS J 280(13):3009-3027. https://doi.org/10.1111/febs.12280

28. Decamps K, Joye IJ, Pareyt B, Courtin CM, Delcour JA (2014) Pyranose oxidase from Trametes multicolor impacts dough and bread microstructure. Cereal Chem 91(4):414-417

29. AACC International (1999) Approved methods of analysis. Method 66-50.01. Pasta and noodle cooking quality-firmness, 11th Ed. AACC International, St. Paul, MN, USA. https://doi. org/10.1094/AACCIntMethod-66-50.01

30. Food and Nutrition Board/Institute of Medicine (2005) Dietary reference intakes (DRI) for energy, carbohydrate, fiber, fat, fatty acids, cholesterol, protein, and amino acids. Institute of Medicine of the National Academies. Washington DC. The National Academy Press, Washington, D.C. URL available in: http://www.nal. usda.gov/sites/default/files/fnic_uploads/energy_full_report.pdf. Access date November 7, 2018

31. David SL (ed) (2011) La quinua Real en el Atiplano Sur de Bolivia. Documento Tecnico para la Denominacion de Origen. La Paz, Bolivia, p 110 (ISBN 978-99954-46-48-2)

32. Amarakoon R (2012) Study on amino acid content in selected varieties of Pisum sativum (peas) by ion exchange chromatography. International Conference on Nutrition and Food Sciences IPCBEE, vol 39. IACSIT Press, Singapore, pp 211-214

33. WHO, FAO, UNU (2007) Protein and Amino acid requirements in human nutrition; report of a joint WHO/FAO/UNU expert consultation, WHO Tech Rep Ser no. 935. WHO, Genova

34. Pereira Monteiro M, Costa A, Campos S, Coelho M (2014) Evaluation of the chemical composition, protein quality and digestibility of lupin (Lupinus albus and Lupinus angustifolius). O Mundo da Saude 38(3):251-259. https://doi.org/10.15343/0104-7809.20143 803251259
35. Gabriel I, Lessire M, Juin J, Burstin J, Duc G, Quillien L, Thibaul JN, Leconte M, Hallouis JM, Ganier P, Mézière N, Sève B (2008) Variation in seed protein digestion of different pea (Pisum sativum L.) genotypes by cecectomized broiler chickens: 1 . Endogenous amino acid losses, true digestibility and in vitro hydrolysis of proteins. Livestock Sci 113(2-3):251-261. https://doi. org/10.1016/j.livsci.2007.04.002

36. Mercier S, Moresoli C, Mondor M, Villeneuve S, Marcos B (2016) A meta-analysis of enriched pasta: what are the effects of enrichment and process specifications on the quality attributes of pasta? Comprehensive reviews in food science and food safety. Inst Food Technol 15:685-704

37. Wang L, Duan W, Zhou S, Qian H, Zhang H, Qi X (2016) Effects of extrusion conditions on the extrusion responses and the quality of brown rice pasta. Food Chem 204:320-325

38. Lamberts L, Gomand SV, Derycke V, Delcour JA (2009) Presence of amylose crystallites in parboiled rice. J Agric Food Chem 57(8):3210-3216

39. Lindeboom N, Chang PR, Falk KC, Tyler R (2005) Characteristics of starch from eight quinoa lines. Cereal Chem 82:216-222

40. Instituto Interamericano de Cooperación para la agricultura (IICA) (2015) El mercado y la producción de la quinua en el Perú. Lima, p 175 (ISBN: 978-92-9248-602-0)

41. Maskan M, Altan A (2011) Advances in food extrusion technology. CRC Press, Boca Raton, p 396

42. Guha M, Ali SZ, Bhattacharya S (1997) Twin-screw extrusion of rice flour without a die: effect of barrel temperature and screw speed on extrusion and extrudate characteristics. J Food Eng 32:251-267

43. Milán-Carrillo J, Reyes-Moreno C, Camacho-Hernández IL, Rouzaud-Sandez O (2002) Optimisation of extrusion process to transform hardened chickpeas (Cicer arietinum L.) into a useful product. J Sci Food Agric 82:1718-1728. https://doi.org/10.1002/ jsfa. 1242

44. Xu J, Mohamed AA (2003) Thermal and rheological properties of lupinus albus flour. J Am Oil Chem Soc 80:763-766. https:// doi.org/10.1007/s11746-003-0769-y

45. Phillips LG, Whitehead DM, Kinsella JE (1994) Structurefunction properties of food proteins. Academic Press, San Diego, p 271 (Food Science and Technology International Series)

46. Campbell L, Raikos V, Euston SR (2003) Modification of functional properties of egg-white proteins. Nahrung Food 47(6):369376. https://doi.org/10.1002/food.200390084

47. Schmidt RH (1981) Gelation and coagulation. In: Cherry JP (ed) Protein functionality in foods. ACS, Washington, pp 131-147

48. Marti A, Barbiroli A, Marengo M, Fongaro L, Iametti S, Pagani MA (2014) Structuring and texturing gluten-free pasta: egg albumen or whey proteins? Eur Food Res Technol 238(2):217-224

49. Schoenlechner R, Drausinger J, Ottenschalaeger V, Jurackova K, Berghofer E (2011) Functional properties of gluten-free pasta produced from amaranth, quinoa and buckwheat. Plants Foods Hum Nutr 65:339-349

Publisher's Note Springer Nature remains neutral with regard to jurisdictional claims in published maps and institutional affiliations. 